\title{
Modulation of the main porcine enteric neuropeptides by a single low-dose of lipopolysaccharide (LPS) Salmonella Enteritidis
}

\author{
Anita Mikołajczyk ${ }^{*} \mathbb{0}$, Sławomir Gonkowski² and Dagmara Złotkowska ${ }^{3}$
}

\begin{abstract}
Background: The present research was conducted to investigate the influence of a low, single dose of LPS, which does not result in any clinical symptoms of intoxication on the expression of selected neuropeptides within the intestines of the domestic pig.

Methods: This experiment was conducted on immature female pigs of the Pitrain $\times$ Duroc breed $(n=$ five per group). Seven days after the intravenous injection of $10 \mathrm{~mL}$ saline solution for control animals and $5 \mathrm{\mu g} / \mathrm{kg}$ b.w. (in $10 \mathrm{~mL}$ saline solution) LPS Salmonella Enteritidis for the experimental group, the excised segments of duodenum, jejunum, ileum, ileocecal valve, caecum, descending colon, transverse colon, ascending colon and rectum were prepared to extract the main enteric neuropeptides, including GAL, NPY, SOM, SP, VIP.

Results: The results of this research indicate that single low-dose LPS S. Enteritidis produced changes in the content of the selected neuropeptides of the porcine intestine. The most visible changes were observed in the transverse colon, where LPS induced the increase of GAL expression from $19.41 \pm 7.121$ to $92.92 \pm 11.447 \mathrm{ng} / \mathrm{g}$ tissue.

Conclusion: The exact functions of the substances studied and mechanisms of responses to LPS action depend on the sections of the intestines. The mechanisms of observed changes are not fully understood, but fluctuations in neuronal active substance levels may be connected with neurodegenerative and/or pro-inflammatory activity of LPS.
\end{abstract}

Keywords: Low-dose lipopolysaccharide, LPS, Salmonella Enteritidis, Neuropeptides, Pig, GAL, NPY, SOM, SP, VIP

\section{Background}

In recent years, a major topic of research interest has been the rise of the impact of the intestinal barrier, pathogenic and non-pathogenic bacteria on etiology and the pathogenesis or clinical course of neurodevelopmental, psychiatric and neurodegenerative diseases, such as depression, Alzheimer's disease and Parkinson's disease. In these pathological processes, neuropeptides have been the main subject of interest for neurodegeneration and neuroprotection. It is known that gastrointestinal

\footnotetext{
*Correspondence: anita.mikolajczyk@uwm.edu.pl

${ }^{1}$ Department of Public Health, Epidemiology and Microbiology, Faculty of Health Sciences, University of Warmia and Mazury in Olsztyn, ul. Warszawska 30 Str., 10-082 Olsztyn, Poland

Full list of author information is available at the end of the article
}

physiology involves complex interactions between the nerve cells and the other non-neuronal cell types, for example, enteroendocrine cells. Their peptide secretory products play a role in the regulation of the gastrointestinal (GI) tract functions. Neuropeptides may have an influence on the activity of the GI microbiota and its interaction with the gut-brain axis [1-3].

It is also well-known that the digestive system is supplied by nerves derived from various neuronal cells. The most important role in the regulation of gastrointestinal (GI) tract functions is played by the enteric nervous system (ENS), which is located in the wall of esophagus, stomach, as well as small and large intestine [4]. The ENS is built of millions of neuronal cells connected by dense nerve fibers and grouped into ganglionated plexuses [5]. 
The number of these plexuses and their exact location clearly depend on the animal species and the fragment of the digestive tract. There are two enteric plexuses in rodents. One of them (myenteric plexus-MP) is placed between the longitudinal and circular muscle layers, while the second (submucosal plexus) is located near the lamina propria of mucosal layer [5]. In the small and large intestine of large animals (including the pig), the submucosal plexus is divided into the outer submucous plexus (OSP) - placed on the internal side of the circular muscle layer-and the inner submucous plexus (ISP) located like the submucosal plexus in rodents [6]. Enteric neurons are very diverse in their morphology, electrophysiological properties, functions and active substances presented within cell bodies [4]. They regulate all roles of the GI tract, including, among others, intestinal motility, mucosal secretion, mesenteric blood flow or absorption of nutrients [4]. Apart from the ENS, the GI is supplied by extrinsic innervation, in which neuronal cells are localized in sympathetic, parasympathetic and sensory ganglia.

Both extrinsic and intrinsic parts of the digestive system innervation can contain a wide range of active substances, which mainly play the role of neuromediators and/or neuromodulators. Apart from classical neurotransmitters, such as acetylcholine and noradrenaline [7], the most important factors taking part in the regulation of digestive functions include vasoactive intestinal polypeptide (VIP), nitric oxide (NO), galanin (GAL), substance P (SP), neuropeptide Y (NPY) and somatostatin (SOM). Some of these substances, besides the nervous system, are also present in enteroendocrine cells of the digestive tract and can play the function of hormones involved in the intestinal regulatory processes.

One of the lesser-known aspects of innervation of the digestive system is the adaptive and/or neuroprotective activity of biologically active substances during various intestinal and extra-intestinal diseases, inflammatory processes and intoxication [8]. Admittedly, it is known that neurons supplying the digestive organs may change their neurochemical coding under the above-mentioned pathological processes and these changes clearly depend on the type of disease [8], although the exact mechanisms of these changes still remain not fully explained.

On the other hand, it is known that Salmonella is one of the common foodborne pathogens and the symptomfree carries of Salmonella spp. are still a significant public health problem. Lipopolysaccharide (LPS, bacterial endotoxin) - a component of the cellular membrane of Gram-negative bacteria-is a very important pathological factor $[9,10]$, which has multidirectional negative effects on the living organism. Lipopolysaccharides from distinct pathogens can induce different responses. First of all, LPS stimulates the release of free radicals and activates the immunological system $[11,12]$, leading to the injury of internal organs, fever, septic shock and often death [9]. Mohammadi et al. [13] observed that endotoxin of gram-negative bacteria is essentially involved in the pathogenesis of critical illness polyneuropathy in septic patients. Niehaus [14] reported that 14 years after a laboratory worker developed Parkinson's syndrome after accidental exposure to Salmonella Minnesota LPS, the lipopolysaccharides had not been detoxified by the body.

Nevertheless, the knowledge concerning the LPSinduced changes in the expression of neuronal active substances within the digestive tract is extremely limited, especially in the case of low doses of bacterial endotoxin.

Therefore, the aim of the present study was to investigate the influence of a "low single dose" of LPS, which does not result in any clinical symptoms of intoxication [15] on expression of selected neuropeptides within the intestines of the domestic pig. The exposure to a low dose Salmonella spp. endotoxin with an absence of clinical symptoms of disease can hypothetically take place during, for example, the asymptomatic carrier state of Salmonella spp. It should be pointed out that this animal species is increasingly used as an animal model of processes within the human body due to relatively well-known similarities between these two species with respect to physiological, biochemical and immunological properties [16], particularly in terms of the innervation of digestive organs [17]. Using the pig as a biomedical model which is phylogenetically closer to humans than rodents, plays a critical role in understanding the physiological and pathophysiological processes in the human body [18].

\section{Results}

During this investigation, there were no differences in behavior, feeding habits or health status between animals of the control and experimental groups. Moreover, both macroscopic abduction after euthanasia, as well as histopathological examinations of the particular fragments of the gastrointestinal tract of experimental animals (performed in a specialized veterinary laboratory at the Department of Pathological Anatomy, Faculty of Veterinary Medicine, University of Warmia and Mazury, Olsztyn [Poland]) did not find any changes in comparison to control animals.

In the present study, the expression of all neuropeptides investigated was observed in all examined parts of the digestive system, both in control animals and in pigs after LPS administration. The highest expression was observed for GAL. In the control animals, the level of this substance exceeded 10 (from $14.96 \pm 1.953 \mathrm{ng} / \mathrm{g}$ tissue in the ileum to $70.02 \pm 11.18 \mathrm{ng} / \mathrm{g}$ tissue in the ileocecal 
valve) in almost all fragments of the gastrointestinal tract studied (Fig. 1). The only exceptions were the duodenum and caecum, where the levels of GAL amounted to $1.73 \pm 0.261$ and $3.21 \pm 0.482 \mathrm{ng} / \mathrm{g}$ tissue, respectively. LPS administration changes the expression of GAL in all fragments of the digestive tract, except the caecum. The character and intensity of changes clearly depended on the intestinal fragment. In particular, the increase of the GAL expression after LPS administration was observed within the duodenum, ileum, ileocecal valve, transverse colon and rectum, whereas in jejunum and the ascending and descending colon, the levels of this substance were clearly lower (Fig. 1). The most visible changes were observed in the transverse colon, where LPS induced the increase of GAL expression from $19.41 \pm 7.121$ to $92.92 \pm 11.447 \mathrm{ng} / \mathrm{g}$ tissue (Fig. 1).

The second substance, whose level underwent LPSinduced changes in relatively numerous parts of the digestive tract, was NPY. In control animals, the expression of this substance fluctuated from $2.77 \pm 0.246 \mathrm{ng} / \mathrm{g}$ tissue in the duodenum to $7.79 \pm 0.839 \mathrm{ng} / \mathrm{g}$ tissue within the transverse colon (Fig. 2). LPS administration caused changes in NPY levels in six investigated fragments of the digestive tract, with their increase within the duodenum and descending colon and a decrease in jejunum, ileum, ascending and transverse colon (Fig. 2). The most visible changes in the expression of NPY after LPS administration were observed in the transverse colon (the decrease from $7.79 \pm 0.839$ to $4.62 \pm 0.272 \mathrm{ng} / \mathrm{g}$ tissue) and ileum (the increase was from $3.59 \pm 0.78$ to $1.63 \pm 0.413 \mathrm{ng} / \mathrm{g}$ tissue). LPS did not change the NPY levels in the ileocecal valve, caecum or rectum (Fig. 2).

In control animals, the levels of VIP fluctuated from $1.50 \pm 0.301 \mathrm{ng} / \mathrm{g}$ tissue in the caecum to

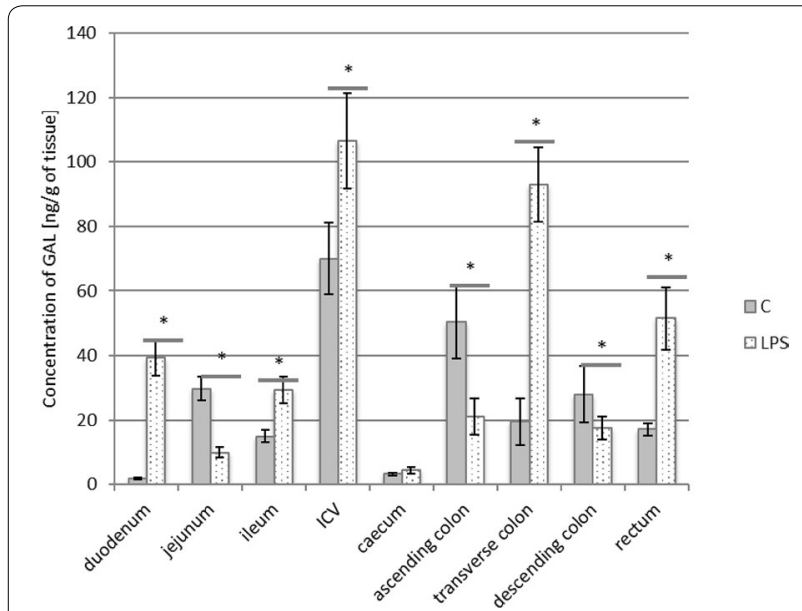

Fig. 1 Galanin level in the intestine sections of control $(n=5)$ and LPS-treated $(n=5)$ swine. *Statistically different for $p<0.05$
$4.62 \pm 0.636 \mathrm{ng} / \mathrm{g}$ tissue in the ileocecal valve (Fig. 3). LPS administration caused changes in VIP expression within the ileocecal valve, transverse and descending colon as well as in the rectum. These changes were manifested by a decrease within the transverse colon (from $3.84 \pm 0.542$ to $2.69 \pm 0.551 \mathrm{ng} / \mathrm{g}$ tissue) and an increase in the other above-mentioned intestinal parts, with the most visible changes in the rectum (from $3.64 \pm 0.671$ to $14.29 \pm 5.346 \mathrm{ng} / \mathrm{g}$ tissue) (Fig. 3).

The levels of SOM observed during the present study in control animals were slightly lower than the expression of VIP and ranged from $0.21 \pm 0.066 \mathrm{ng} / \mathrm{g}$ tissue in the duodenum to $1.82 \pm 0.314 \mathrm{ng} / \mathrm{g}$ tissue in the ileum (Fig. 4). LPS administration induced a decrease of SOM levels in the
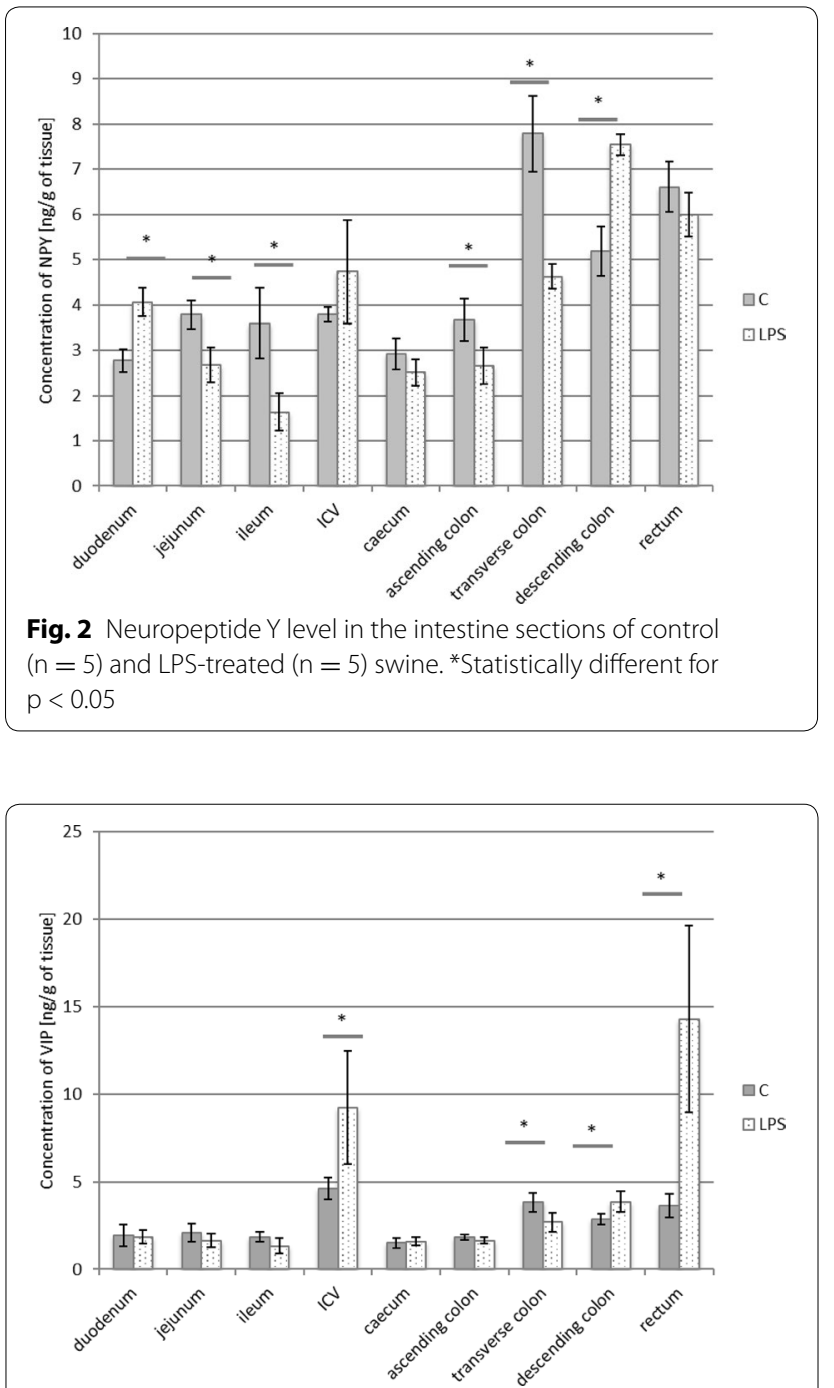

Fig. 3 Vasoactive intestinal peptide level in the intestine sections of control $(n=5)$ and LPS-treated $(n=5)$ swine. * Statistically different for $p<0.05$ 


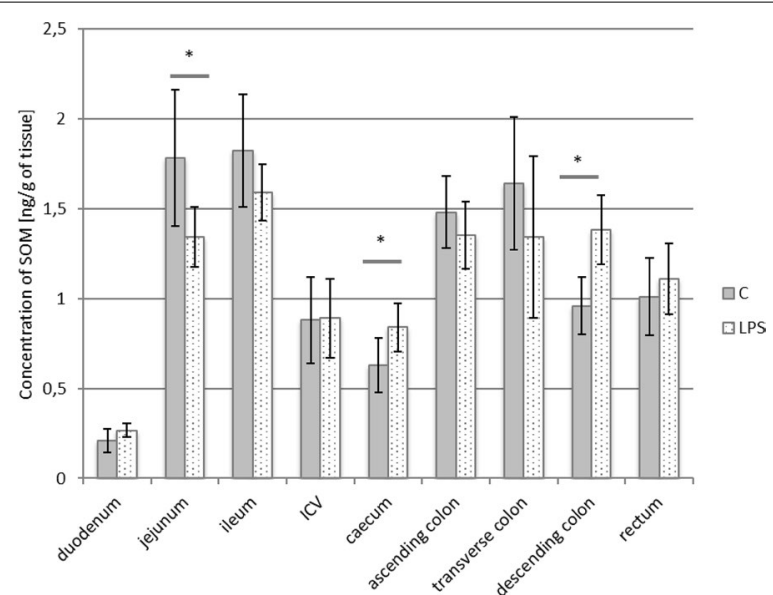

Fig. 4 Somatostatin level in the intestine sections of control $(n=5)$ and LPS-treated $(n=5)$ swine. *Statistically different for $p<0.05$

jejunum (from $1.78 \pm 0.379$ to $1.34 \pm 0.167 \mathrm{ng} / \mathrm{g}$ tissue), while within caecum and descending colon an increase of SOM expression was observed (from $0.63 \pm 0.153$ to $0.84 \pm 0.134 \mathrm{ng} / \mathrm{g}$ tissue and from $0.96 \pm 0.157$ to $1.38 \pm 0.192 \mathrm{ng} / \mathrm{g}$ tissue, respectively) (Fig. 4).

In turn, the expression of SP was relatively high in all investigated parts of the digestive tract (Fig. 5). In control animals, it fluctuated from $6.95 \pm 0.704 \mathrm{ng} / \mathrm{g}$ tissue in the duodenum to above $27 \mathrm{ng} / \mathrm{g}$ tissue in the transverse and descending colon. Contrary to the other neuropeptides studied, LPS changed SP levels only in two segments of the digestive tract. An increase in the expression of SP was observed in the ascending colon (from $18.17 \pm 4.616$ to $25.62 \pm 4.71 \mathrm{ng} / \mathrm{g}$ tissue), while within the duodenum a decrease in SP levels was noted (from $6.95 \pm 0.704$ to $2.98 \pm 0.355 \mathrm{ng} / \mathrm{g}$ tissue).

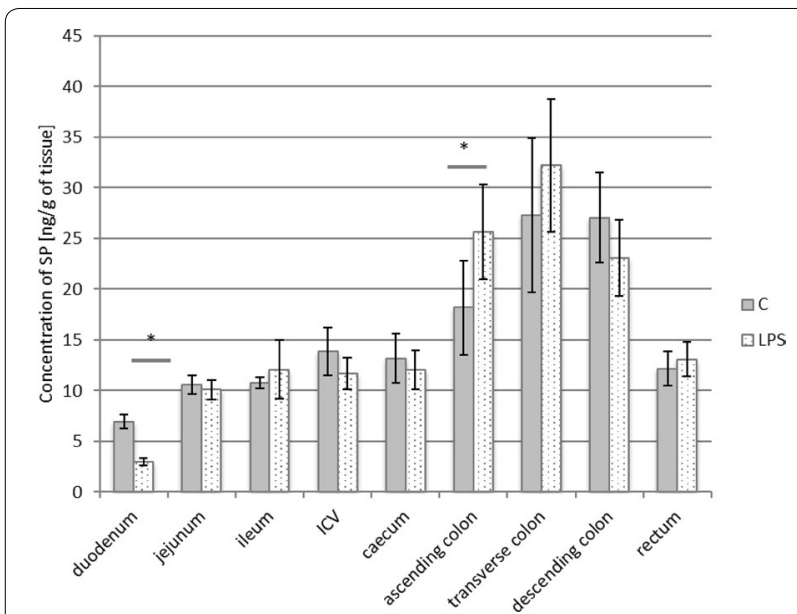

Fig. 5 Substance $P$ level in the intestine sections of control $(n=5)$ and LPS-treated $(n=5)$ swine. *Statistically different for $p<0.05$

\section{Discussion}

The obtained results show the presence of all neuropeptides studied in all investigated parts of the digestive system and, hence, confirm the participation of these factors in regulatory processes during digestion and absorption of nutrients, which is in agreement with previous studies $[4,5]$.

Moreover, it is known that the exact roles of substances studied in the present investigation may depend on the fragment of the intestine [4]. First of all, such a situation has been observed in the case of GAL. This substance takes part in the regulation of gut motility, secretion and other neurotransmitters released by the influence on voltage-dependent $\mathrm{Ca}^{2+}$ channels [19-21]. The exact effects of GAL on the alimentary system are different in various animal species. For example, GAL induces smooth muscle contraction in the ileum of the rat, guinea-pig, rabbit and pig [22], while in the canine pylorus and ileum it exhibits relaxatory effects [19]. The results obtained during the present study and significant differences in GAL expression in particular, even contiguous segments of intestine, seems to support the multidirectional activity of this substance. Multidirectional influence on intestinal muscles has been also described in studies on SP, which, acting on the NK3 receptor, causes their contraction and their connection with NK1 receptor shows relaxatory effects [23]. Moreover, SP is considered to be one of the most important neurotransmitters involved in sensory and pain conduction [24], as well as the regulator of blood flow and secretory activity of the digestive system [23]. Other substances studied during the present experiment (NPY, SOM, VIP) have been described within the digestive system as inhibitory factors, which may influence both intestinal motility and secretion [25-27], as well as on mesenteric blood flow [28]. The significant differences in the expression of neuropeptides in particular parts of the digestive system in control animals, as well as various character of changes after LPS administration observed during the present study are probably connected with different exact roles of these substances depending on the fragment of the GI tract.

Moreover, the results of the present study show that LPS may be one of factors affecting the expression of neuropeptides within the digestive system. Previous studies described a wide range of pathological processes and toxic chemical compounds have such properties. The most important of them are inflammatory processes [8], nerve fiber damage [16], mycotoxins [29, 30], extra-intestinal metabolic diseases [31] and psychiatric and neurodegenerative diseases, such as depression or Parkinson's disease (PD) [32, 33].

Maes et al. [32] confirmed an increased gastrointestinal permeability with a translocation of lipopolysaccharide 
from gram-negative bacteria may induce depressive symptoms. An understanding of the fact that enterobacteria have antigenic sites which are very similar to those of the lipid structures of neuronal tissue may be crucial for the identification of risk factors of major depressive disorder. The influence of toxins such as MPTP on neurons in the ENS has been associated with the development of PD symptoms. According to Anderson et al. [34], the MPTP PD model was a selective dopaminergic neurotoxin in the ENS and caused changes in colonic motility. In addition to the MPTP PD model, several animal models, for example, the lipopolysaccharide PD model or the rotenone PD model, can reproduce aspects of PD pathology [35, 36]. The enteric nervous system, with their neurons and enteric glial cells which are involved in the regulation of neurotransmission, could be critical in the pathophysiology of Parkinson's disease [37, 38]. The results of this research indicate that LPS $S$. Enteritidis involved changes in the content of the main neuropeptides (GAL, NPY, SOM, SP, VIP) of the porcine enteric nervous system (Figs. 1, 2, 3, 4, 5). But it is also known that not only pathological agents, but also physiological factors, including the growth and development of the living organism or the diet modification may change the ENS [39].

It should be pointed out that the mechanism of these neuropeptides changes still remains unclear. Fluctuations in the expression of neuropeptides are intended for the protection of secretory cells and adaption of the nervous system to functioning in amended (pathological) conditions $[8,40]$. Moreover, a low dose of LPS is known as one of the factors that may change the number and chemical coding of enteric neurons, but knowledge of this subject is extremely limited. In particular, it is known that a single low dose of LPS may cause an increase in the number of intramural gallbladder nerves immunoreactive to a wide range of neuronal factors, including, among others, SP, NPY and GAL, but the mechanisms of these processes are completely unknown [41, 42]. On the other hand, the neuroprotective properties of the majority of substances studied during the present experiment have been reported in previous investigations [4, 8]. Moreover, it is known that they also may affect the inflammatory processes. For example, VIP inhibits the activity of macrophages [43] and SP stimulates the synthesis of interleukins and tumor necrosis factor [23]. In turn, SOM takes part in various pathological processes within the digestive system [44], reduces pain sensation during intestinal inflammation, regulates the immunological response and may act as an anti-inflammatory factor [45].

Previous studies have also described the functions of substances studied in the present investigation during LPS intoxication. It should be pointed out that the knowledge concerning the influence of LPS on the expression of neuropeptides investigated during the present study is very scanty and not limited to experiments on low single doses of bacterial endotoxin. Most of the information concerns the roles of VIP in the immune maintenance during LPS intoxication [46]. It is known that VIP may affect the monocytes stimulated by LPS, and this activity manifests itself in an increase of IL-10, IL-6 and TNF $\alpha$ synthesis [47], which can suggest the possibility of using VIP in adjunctive therapy to antibiotic treatments $[48,49]$. On the other hand, some studies have reported that a deficiency of VIP may support resistance to lipopolysaccharide-induced endotoxemia [50]. The results of this research indicate that LPS administration caused a decrease in VIP expression in the transverse colon. Similarly, a decrease in the number of enteric neurons of submucosal plexuses containing VIP was detected by colonoscopy in parkinsonian patients with chronic constipation [33]. Moreover, VIP is a factor that participates in the rescue of enteric neurons from LPS-induced cell death [51]. In the present research, an increase in VIP expression was observed in the ileocecal valve and the transverse and descending colon and in the rectum. Similar neuroprotective functions under LPS action are characteristic of SOM [52], which can also modulate the production of cytokines and chemokines by monocytes treated with bacterial endotoxins [53]. In turn, galanin mRNAs synthesis in the lateral hypothalamic area is reduced under bacterial endotoxin administration [54], and GAL (like NPY and SP) stabilizes body temperature and shows antipyretic effects in an experimental LPS-induced pyrogenic reaction [55-57]. Moreover, NPY modulates immunoreactive reactions after LPS administration [58], improves blood pressure and staves off hypotension during endotoxic shock [59].

Above all, the fluctuations in the expression of neuropeptides noted during the present investigation may be connected with the relatively well-known inflammatory activity of LPS. This activity is connected with the influence of lipid A (one of the components of LPS on macrophages, monocytes and neutrophils), which results in an increase in pro-inflammatory factor synthesis, especially TNF- $\alpha[9,11]$. Such supposition is in agreement with previous studies, where the participation of various neuronal factors in processes connected with inflammatory-induced immunological response has been described [8]. On the other hand, low doses of LPS (which did not result in inflammatory processes) were used in the present experiment. However, it seems likely that subclinical inflammatory activity takes place even in the case of low LPS doses.

The second reason for the observed changes may be neuroprotective and/or adaptive processes that respond 
to LPS-induced disturbances in homeostasis. It is more likely that all neuropeptides studied have been previously described as substances taking part in the protection of the nervous system against different damaging factors $[4,5,8]$. At the same time, LPS is a relatively well-known factor, which may be involved in neurodegenerative processes within the central and peripheral nervous system $[60,61]$ and these effects are so intense that LPS is one of the substances used to chemically-induce Parkinson's disease in animal models [62]. Thus, the changes observed during the present study may help protect the intestinal neuronal structures from the neurodegenerative activity of LPS, particularly through the participation of nerves supplying the gastrointestinal tract in reduction of LPSinduced pathological changes as described in previous studies [63].

It cannot be excluded that the observed changes are connected with other direct influences on the nervous system, including the blockade of synaptic transmissions and/or the influence on sensory stimuli conduction $[64,65]$. Moreover, the mechanism of fluctuations in the expression of biologically-active substances is also unclear. It may be connected with changes during transcription, translation, post-translational modification of peptides and/or alterations (disturbances or augmentation) of axonal transport, especially from neuronal cell bodies located outside the digestive organs to nerves supplying them.

\section{Conclusion}

To sum up, the obtained results clearly show that even low doses of LPS, which simulate the asymptomatic carrier state of Salmonella spp., may affect the expression of neuropeptides in the digestive system. Moreover, significant differences in the intensity and character of observed changes between particular parts of the digestive system strongly suggest that the exact functions of the substances studied and mechanisms of responses to LPS action depend on the fragment of the gastrointestinal tract. The observed changes are probably connected with the neurodegenerative activity of LPS. On the other hand, due to the multidirectional influence of LPS on the living organism, as well as the diverse functions of particular neuropeptides, the full elucidation of the investigated fluctuations is very difficult and requires further studies.

\section{Methods}

\section{Animals and experimental procedures}

This experiment was conducted on 10 immature female pigs of the Pitrain $\times$ Duroc breed. The pigs were maintained in individual pens with an area of about $4 \mathrm{~m}^{2}$ with a 12-h-long light cycle for 2 weeks prior to the experiment in order to allow adaptation to the new environment. The experiments were conducted when the pigs were 8-9 weeks of age with body weights of $16-18 \mathrm{~kg}$. All animals included in the experiment were clinically healthy and were not carriers of Salmonella spp., which was excluded by standard fecal analysis tests. Pigs during experiment were nourished with feed appropriate for pigs of this age group (twice a day in the quantity recommended by producer) and had an access to water ad libitum. All procedures during this investigation were performed according to the recommendations of the Local Ethical Committee for Animal Experimentation in Olsztyn (Poland) (Decision no. 73/2015 from 29th Sept 2015).

After a 2-week adaptive period, pigs included in the experiment were randomly divided into two groups (five pigs in each group): control group ( $C$ group) and experimental (LPS group). Animals of both these groups were subjected to premedication, according to the method previously described by Mikolajczyk [66] with intramuscular injection of atropine (Atropinum Sulfuricum Polfa Warszawa S.A., Poland, $0.035 \mathrm{mg} / \mathrm{kg}$ b.w.), ketamine (Bioketan, Vetoquinol Biowet Sp. z o.o., Poland and Vetoquinol S.A., France, $7.0 \mathrm{mg} / \mathrm{kg}$ b.w.) and medetomidine (Cepetor, CP-Pharma Handelsges $\mathrm{mbH}$, Germany, $0.063 \mathrm{mg} / \mathrm{kg}$ b.w.). The premedication of animals allowed accurate and safe (for investigators) injections of LPS. Premedication of control animals was performed to maintain the same conditions for all animals.

Under premedication, the control animals were injected with a $10 \mathrm{~mL}$ saline solution, while pigs of the experimental group received lipopolysaccharides from Salmonella enterica serotype Enteritidis (catalogue no. L7770 Sigma, Aldrich, Germany) at a dose of $5 \mu \mathrm{g} / \mathrm{kg}$ b.w. (in $10 \mathrm{~mL}$ saline solution). Such a dose has been previously described as a "low single dose" which does not result in any clinical symptoms of intoxication [15, 67, 68]. Injections in control and experimental animals were performed in the same way, i.e. intravenously into the marginal ear vein. All procedures and drugs were managed and administered by a veterinary doctor (DVM, Ph.D.).

After a 7-day period which has been described as sufficient for the emergence of changes in the nervous system in the previous studies $[69,70]$ all animals were again premedicated (in the above-described manner) and subjected to general anesthesia using propofol (Scanofol, NORBROOK, Northern Ireland, IRL.PN, $4.5 \mathrm{mg} /$ $\mathrm{kg}$ b.w. given intravenously), and then euthanized with pentobarbital (Morbital, Biowet Puławy Sp. z o.o, Poland, 60-70 mg/kg b.w., given intravenously). After euthanasia, the excised segments of duodenum, jejunum, ileum, ileocecal valve (ICV), caecum, descending colon, transverse 
colon, ascending colon and rectum (the same fragments from all animals) were washed in $0.9 \% \mathrm{NaCl}$, and then packed, frozen in liquid nitrogen and stored at $-80{ }^{\circ} \mathrm{C}$ until analysis.

\section{A sample preparation and solid-phase extraction (SPE)}

Neuropeptide extracts from tissue were prepared according to the Conlon procedure [71]. Briefly, frozen tissues were weighed and cut into small pieces. $10 \mathrm{~mL}$ of hot $1 \mathrm{M}$ acetic acid was added per gram tissue and boiled for $5 \mathrm{~min}$. The samples were then homogenized using Ultra Turax IKA T-25 (Jankel \& Kunkel IKA, Germany) at RT for $5 \mathrm{~min}$ and centrifuged at $4{ }^{\circ} \mathrm{C}$ for $40 \mathrm{~min}$ at $4500 \times g$ (Eppendorf 5804). The supernatant was filtered by syringe filter with a graduated glass fiber pre-filter (Millex-HPF HV Filter, $0.45 \mu \mathrm{m}$, PVDF, Milipore). TFA were added to filtrates to obtain a final concentration of $0.1 \%$ (vol/vol). In the SPE method, silica-based cartridges (Sep-Pak Short $360 \mathrm{mg}$ C18, Waters) were used according to the producer's protocol using a Baker Vacuum Manifold SPE-12G (J.T.Baker, Germany). Samples were concentrated on miVac centrifugal vacuum concentrators, model DNA-23050-800 with SpeedTrap (Genevac Limited, UK) for $2 \mathrm{~h}$, then lyophilized using an ALPHA 1-4 LSC freeze dryer (MARTIN CHRIST Gefriertrocknungsanlagen $\mathrm{GmbH}$ Germany). Lyophilized samples were stored at $-80^{\circ} \mathrm{C}$ until analysis.

The chemicals used for extraction: glacial acetic acid (cat. no. 951503, J.T. Baker), trifluoroacetic acid -TFA (cat. no. 9470, J.T. Baker) and acetonitrile-LC-MS reagent (cat. no. 9821.1000, J.T. Baker) were of high purity grade-HPLC grade.

\section{Enzyme immunoassay for quantitative determination of neuropeptides in tissue extracts}

Phoenix Pharmaceuticals, Inc. tests for Vasoactive Intestinal Peptide (0-25 ng/mL; cat. no. EK-064-16CE), Neuropeptide Y (0-100 ng/mL; cat. no. EK-049-03CE), Somatostatin-28 (0-25 ng/mL; cat. no. EK-060-14CE) were used for VIP NPY and SOM determination, respectively. The standard protocol proposed by the manufacturer for kits in the ranges of $0-25$ and $0-100 \mathrm{ng} / \mathrm{mL}$ was used. Briefly, $50 \mu \mathrm{L}$ of standard, sample or positive control, together with $25 \mu \mathrm{L}$ of primary antibody and $25 \mu \mathrm{L}$ of biotinylated peptide were put on a plate and incubated for $2 \mathrm{~h}$ at room temperature. The plate was then washed four times with a $350 \mu \mathrm{L}$ of assay buffer and then $100 \mu \mathrm{L}$ of streptavidin conjugated with HRP was added. After $1 \mathrm{~h}$ incubation and a washing step, $100 \mu \mathrm{L}$ of TMB substrate was added to each well and the plates were incubated again for $1 \mathrm{~h}$ et RT. Reaction was terminated with $100 \mu \mathrm{L} /$ well of $2 \mathrm{~N} \mathrm{HCl}$. Absorbance was read at $\lambda=450 \mathrm{~nm}$ on Infinite 200 (Tecan) for each sample.
Peninsula Laboratories International, Inc. tests for Substance P (0-5 ng/mL; cat. no. S-1180), GalaninGAL (0-10 ng/m; cat. no. S-1210) were used for SP and GAL determination, respectively. The protocol proposed by the manufacturer to increase sensitivity was used. Briefly, $50 \mu \mathrm{L}$ of standard or sample, together with $25 \mu \mathrm{L}$ of the primary antibody, were incubated overnight at $4{ }^{\circ} \mathrm{C}$. The plates were then incubated at RT for $1 \mathrm{~h}$ and $25 \mu \mathrm{L}$ of biotinylated tracer was added to the each well and incubated for $2 \mathrm{~h}$ at room temperature. The plates were washed five times with $300 \mu \mathrm{L}$ of EIA buffer and $100 \mu \mathrm{L}$ of streptavidin conjugated with HRP were added. After $1 \mathrm{~h}$ incubation and a washing step, $100 \mu \mathrm{L}$ of TMB substrate were added to each well and the plates were incubated for about 30-60 min at RT. The reaction was terminated with a $100 \mu \mathrm{L} /$ well of $2 \mathrm{~N} \mathrm{HCl}$. Absorbance was read at $\lambda=450 \mathrm{~nm}$ on Infinite 200 (Tecan).

The ELISA four parameter curve was prepared for each neuropeptide (an Excel sheet was provided by Penisula Laboratories service). Samples were assayed in duplicate. The concentration in each sample was read from the curve. Final peptide concentration was presented as ng per $g$ of analyzed tissue and presented as the mean from group \pm SD.

\section{Statistical analyses}

The results were analyzed statistically using a one-way analysis of variance (ANOVA) and the significance of differences between groups was determined using Duncan's multiple-range test at a significance level of $\mathrm{p}<0.05$. The data are expressed as mean values \pm SD. Calculations were made with SigmaPlot ${ }^{\circledR} 12$ (Systat Software Inc.)

\section{Authors' contributions \\ AM conceived and designed the study, performed the experimental proce- dures and protocols and prepared and edited the manuscript. SG helped to perform a part of the experiment. DZ helped to perform a part of the experi- ment. All authors read and approved the final manuscript.

\begin{abstract}
Author details
${ }^{1}$ Department of Public Health, Epidemiology and Microbiology, Faculty of Health Sciences, University of Warmia and Mazury in Olsztyn, ul. Warszawska 30 Str., 10-082 Olsztyn, Poland. ${ }^{2}$ Department of Clinical Physiology, Faculty of Veterinary Medicine, University of Warmia and Mazury in Olsztyn, Oczapowskiego 13 Str., 10-718 Olsztyn, Poland. ${ }^{3}$ Department of Food Immunology and Microbiology, Institute of Animal Reproduction and Food Research, Polish Academy of Sciences in Olsztyn, Tuwima 10 Str., 10-748 Olsztyn, Poland.
\end{abstract}

\section{Acknowledgements}

Not applicable.

\section{Competing interests}

The authors declare that they have no competing interests.

Availability of data and materials

The datasets used and/or analyzed during the current study are available from the corresponding author on reasonable request. 


\section{Consent for publication}

Not applicable.

\section{Ethics approval and consent to participate}

This study was approved by the Local Ethics Committee for Animal Experimentation in Poland (The permit no. 73/2015 of 29 Sept 2015) and conforms with the provisions of the Declaration of Helsinki (as revised in Brazil in 2013). All procedures during this investigation were performed according to the recommendations of the Local Ethics Committee for Animal Experimentation in Olsztyn (Poland) (Decision no. 73/2015 of 29 Sept 2015)

\section{Funding}

Funding for the study was provided from a statute grant of the Faculty of Medical Sciences of the University of Warmia and Mazury, no. 25.610.001-300.

\section{Publisher's Note}

Springer Nature remains neutral with regard to jurisdictional claims in published maps and institutional affiliations.

Received: 31 October 2017 Accepted: 6 December 2017 Published online: 12 December 2017

\section{References}

1. Bested AC, Logan AC, Selhub EM. Intestinal microbiota, probiotics and mental health: from Metchnikoff to modern advances: part II—contemporary contextual research. Gut Pathog. 2013;5:3. https://doi. org/10.1186/1757-4749-5-3

2. Biaggini K, Borrel V, Szunerits $S$, et al. Substance $P$ enhances lactic acid and tyramine production in Enterococcus faecalis $\mathrm{V} 583$ and promotes its cytotoxic effect on intestinal Caco-2/TC7 cells. Gut Pathog. 2017:9:20. https://doi.org/10.1186/s13099-017-0171-3.

3. Dlugosz A, Muschiol S, Zakikhany K, Assadi G, D'Amato M, Lindberg G. Human enteroendocrine cell responses to infection with Chlamydia trachomatis: a microarray study. Gut Pathog. 2014;6:24. https://doi. org/10.1186/1757-4749-6-24.

4. Furness JB, Callagha BP, Rivera LR, Cho HJ. The enteric nervous system and gastrointestinal innervation: integrated local and central control. Adv Exp Med Biol. 2014;817:39-71. https://doi.org/10.1007/978-1-4939-0897-4_3.

5. Furness JB. The enteric nervous system and neurogastroenterology. Nat Rev Gastroenterol Hepatol. 2012;9(5):286-94. https://doi.org/10.1038/ nrgastro.2012.32.

6. Gonkowski S. Substance P as a neuronal factor in the enteric nervous system of the porcine descending colon in physiological conditions and during selected pathogenic processes. Biofactors. 2013;39:542-51. https://doi.org/10.1002/biof.1097.

7. Burliński PJ, Rychlik A, Całka J. Effects of inflammation and axotomy on expression of acetylcholine transferase and nitric oxide synthetase within the cocaine- and amphetamine-regulated transcript-immunoreactive neurons of the porcine descending colon. J Comp Pathol. 2014;150(23):287-96. https://doi.org/10.1016/j.jcpa.2013.08.007.

8. Vasina V, Barbara G, Talamonti L, Stanghellini V, Corinaldesi R, Tonini M, De Ponti F, De Giorgio R. Enteric neuroplasticity evoked by inflammation. Auton Neurosci. 2006;126-127:264-72. https://doi.org/10.1016/j. autneu.2006.02.025.

9. Steimle A, Autenrieth IB, Frick JS. Structure and function: lipid A modifications in commensals and pathogens. Int J Med Microbiol. 2016;306:290301. https://doi.org/10.1016/j.ijmm.2016.03.001.

10. Whitfield C, Trent MS. Biosynthesis and export of bacterial lipopolysaccharides. Annu Rev Biochem. 2014;83:99-128. https://doi.org/10.1146/ annurev-biochem-060713-035600.

11. Mohammadi Z. Endotoxin in endodontic infections: a review. J Calif Dent Assoc. 2011:39(3):153-61.

12. Vatanen $T$, Kostic AD, d'Hennezel E, Siljander H, Franzosaet EA, et al. Variation in microbiome LPS immunogenicity contributes to autoimmunity in humans. Cell. 2016;165(4):842-53. https://doi.org/10.1016/j. cell.2016.04.007.
13. Mohammadi B, Schedel I, Graf K, Teiwes A, Heckeret H, et al. Role of endotoxin in the pathogenesis of critical illness polyneuropathy. J Neurol. 2008;255(2):265-72.

14. Niehaus I. In vivo Radiodetoxification of Salmonella minnesota Lipopolysaccharides with radio-labeled leucine enkephalin cures sensory polyneuropathy: a Case report. TNHJ. 2010;10(1-2):26-33.

15. Webel DM, Finck BN, Baker DH, Johnson RW. Time course of increased plasma cytokines, cortisol, and urea nitrogen in pigs following intraperitoneal injection of lipopolysaccharide. J Anim Sci. 1997;75:1514-20.

16. Verma N, Rettenmeier AW, Schmitz-Spanke S. Recent advances in the use of Sus scrofa (pig) as a model system for proteomic studies. Proteomics. 2011;11:776-93. https://doi.org/10.1002/pmic.201000320.

17. Brown DR, Timmermans JP. Lessons from the porcine enteric nervous system. Neurogastroenterol Motil. 2004;16(Suppl 1):50-4. https://doi. org/10.1111/j.1743-3150.2004.00475.x

18. Groenen MMM, Archibald AL, Uenishi H, Tuggle ChK, Takeuchi Y, et al. Analyses of pig genomes provide insight into porcine demography and evolution. Nature. 2012:491(11):393-8. https://doi.org/10.1038/ nature11622.

19. Fox-Threlkeld JA, McDonald TJ, Cipris S, Woskowska Z, Daniel EE. Galanin inhibition of vasoactive intestinal polypeptide release and circular muscle motility in the isolated perfused canine ileum. Gastroenterology. 1991;101:1471-6.

20. Piqueras L, Taché $Y$, Martinez V. Galanin inhibits gastric acid secretion through a somatostatin —independent mechanism in mice. Peptides. 2004;25:1287-95. https://doi.org/10.1016/j.peptides.2004.06.003.

21. Sarnelli G, Vanden Berghe P, Raeymaekers P, Janssens J, Tack J. Inhibitory effects of galanin on evoked $\left(\mathrm{Ca}^{2+}\right)$ responses in cultured myenteric neurons. Am J Physiol Gastrointest Liver Physiol. 2004:286:1009-14.

22. Botella A, Delvaux M, Frexinos J, Bueno L. Comparative effects of galanin on isolated smooth muscle cells from ileum in five mammalian species. Life Sci. 1992;50:1253-61.

23. Shimizu Y, Matsuyama H, Shiina T, Takewaki T, Furness JB. Tachykinins and their functions in the gastrointestinal tract. Cell Mol Life Sci. 2008;65:295-311.

24. Brehmer A, Croner R, Dimmler A, Papadopoulos T, Schrödl F, Neuhuber W. Immunohistochemical characterization of putative primary afferent (sensory) myenteric neurons in human small intestine. Auton Neurosci. 2004;112:49-59. https://doi.org/10.1016/j.autneu.2004.03.005.

25. Low MJ. The somatostatin neuroendocrine system: physiology and clinical relevance in gastrointestinal and pancreatic disorders. Best Pract Res Clin Endocrinol Metab. 2004;18:607-22.

26. Cox HM. Neuropeptide $Y$ receptors; antisecretory control of intestinal epithelial function. Auton Neurosci Basic Clin. 2007:133:76-85. https:// doi.org/10.1016/j.autneu.2006.10.005

27. Kasparek MS, Fatima J, Iqbal CW, Duenes JA, Sarr MG. Role of VIP and substance $P$ in NANC innervation in the longitudinal smooth muscle of the rat jejunum influence of extrinsic denervation. J Surg Res. 2007:141:22-30.

28. Lamers CB. Clinical and pathophysiological aspects of somatostatin and the gastrointestinal tract. Acta Endocrinol Suppl (Copenh). 1987;286:19-25.

29. Makowska K, Gonkowski S, Zielonka L, Dabrowski M, Calka J. T2 toxininduced changes in cocaine- and amphetamine-regulated transcript (CART)-like immunoreactivity in the enteric nervous system within selected fragments of the porcine digestive tract. Neurotox Res. 2017;31(1):136-47. https://doi.org/10.1007/s12640-016-9675-8.

30. Makowska K, Obremski K, Zielonka L, Gonkowski S. The influence of low doses of zearalenone and T-2 toxin on calcitonin gene related peptide-like immunoreactive (CGRP-LI) neurons in the ENS of the porcine descending colon. Toxins (Basel). 2017. https://doi.org/10.3390/ toxins9030098.

31. Azpiroz F, Malagelada C. Diabetic neuropathy in the gut: pathogenesis and diagnosis. Diabetologia. 2016;59(3):404-8. https://doi.org/10.1007/ s00125-015-3831-1.

32. Maes M, Kubera M, Leunis JC. The gut-brain barrier in major depression: intestinal mucosal dysfunction with an increased translocation of LPS from gram negative enterobacteria (leaky gut) plays a role in the inflammatory pathophysiology of depression. Neuro Endocrinol Lett. 2008:29(1):117-24. 
33. Giancola F, Torresan F, Repossi R, Bianco F, Latorre R, loannou A, Guarino M, Volta U, Clavenzani P, Mazzoni M, Chiocchetti R, Bazzoli F, Travagli RA, Sternini C, De Giorgio R. Downregulation of neuronal vasoactive intestina polypeptide in Parkinson's disease and chronic constipation. Neurogastroenterol Motil. 2016;29(5):1-9. https://doi.org/10.1111/nmo.12995.

34. Anderson G, Noorian AR, Taylor G, Anitha M, Bernhard D, Srinivasan S, Greene JG. Loss of enteric dopaminergic neurons and associated changes in colon motility in an MPTP mouse model of Parkinson's disease. Exp Neurol. 2007;207(1):4-12. https://doi.org/10.1016/j. expneurol.2007.05.010.

35. Liu B. Modulation of microglial pro-inflammatory and neurotoxic activity for the treatment of Parkinson's disease. AAPS J. 2006;8(3):606-21. https:// doi.org/10.1208/aapsj080369.

36. Lebouvier T, Chaumette T, Paillusson S, Duyckaerts C, Bruley des Varannes S, Neunlist M, Derkinderen P. The second brain and Parkinson's disease. Eur J Neurosci. 2009;30(5):735-41. https://doi. org/10.1111/j.1460-9568.2009.06873.x.

37. Clairembault T, Leclair-Visonneau L, Neunlist M, Derkinderen P. Enteric glial cells: new players in Parkinson's disease? Mov Disord. 2015;30(4):4948. https://doi.org/10.1002/mds.25979.

38. Klingelhoefer $\mathrm{L}$, Reichmann $\mathrm{H}$. Pathogenesis of Parkinson disease-the gut brain axis and environmental factors. Nat Rev Neurol. 2015;11:625-36. https://doi.org/10.1038/nrneurol.2015.197.

39. Bertrand PP, Polglaze KE, Chen H, Sandow SL, Walduck A, Jenkins TA, Bertrand RL, Lomax AE, Liu L. Excitability and synaptic transmission in the enteric nervous system: does diet play a role? Adv Exp Med Biol. 2016:891:201-11. https://doi.org/10.1007/978-3-319-27592-5_19.

40. Voss U, Ekblad E. Lipopolysaccharide-induced loss of cultured rat myenteric neurons - role of AMP-activated protein kinase. PLOS ONE. 2014;9(12):11-7. https://doi.org/10.1371/journal.pone.0114044.

41. Mikołajczyk A, Makowska K. Cocaine- and amphetamine-regulated transcript peptide (CART) in the nerve fibers of the porcine gallbladder wall under physiological conditions and after Salmonella Enteritidis lipopolysaccharides administration. Folia Morphol (Warsz). 2017. https:// doi.org/10.5603/fm.a2017.0036.

42. Makowska K, Mikolajczyk A, Calka J, Gonkowski S. Neurochemical characterization of nerve fibers in the porcine gallbladder wall under physiological conditions and after the administration of Salmonella Enteritidis lipopolysaccharides (LPS). Toxicol Res. 2017. https://doi.org/10.1039/ c7tx00211d.

43. Higyno PM, Mendes PF, Miranda MB, Pereira DE, Mota AP, Nogueira Kde O, Caldas IS, Moura SA, Menezes CA. Vasoactive intestinal peptide reduces the inflammatory profile in mice infected with Trypanosoma cruzi. Exp Parasitol. 2015;159:72-8. https://doi.org/10.1016/j.exppara.2015.09.004.

44. Gonkowski S, Całka J. Changes in the somatostatin (SOM)-like immunoreactivity within nervous structures of the porcine descending colon under various pathological factors. Exp Mol Pathol. 2010;88(3):416-23. https:// doi.org/10.1016/j.yexmp.2010.01.011.

45. Chowers Y, Cahalon L, Lahav M. Somatostatin through its specific receptor inhibits spontaneous and TNF-alpha and bacteria-induced IL-8 and IL-1 beta secretion from intestinal epithelial cells. J Immunol. 2000;165(6):2955-61.

46. Fraccaroli L, Grasso E, Hauk V, Cortelezzi M, Pérez Leirós C, Ramhorst R. Contribution of vasoactive intestinal peptide to immune homeostasis in trophoblast-maternal leukocyte interaction under LPS stimulation. Neurolmmunomodulation. 2014;21(1):21-30. https://doi. org/10.1159/000355039.

47. Askar B, Ibrahim H, Barrow P, Foster N. Vasoactive intestinal peptide (VIP) differentially affects inflammatory immune responses in human monocytes infected with viable Salmonella or stimulated with LPS. Peptides. 2015;71:188-95. https://doi.org/10.1016/j.peptides.

48. Ibrahim H, Barrow P, Foster N. VIP as a potential therapeutic agent in gram negative sepsis. Endocr Metab Immune Disord Drug Targets. 2012;12(4):308-15.

49. Campos-Salinas J, Cavazzuti A, O’Valle F, Forte-Lago I, Caro M, Beverley SM, Delgado M, Gonzalez-Rey E. Therapeutic efficacy of stable analogues of vasoactive intestinal peptide against pathogens. J Biol Chem. 2014;289(21):14583-99. https://doi.org/10.1074/jbc.M114.560573.

50. Abad C, Tan YV, Cheung-Lau G, Nobuta H, Waschek JA. VIP deficient mice exhibit resistance to lipopolysaccharide induced endotoxemia with an intrinsic defect in proinflammatory cellular responses. PLOS ONE. 2012;7(5):1-9. https://doi.org/10.1371/journal.pone.0036922.

51. Arciszewski MB, Sand E, Ekblad E. Vasoactive intestinal peptide rescues cultured rat myenteric neurons from lipopolysaccharide induced cell death. Regul Pept. 2008;146(1-3):218-23. https://doi.org/10.1016/j. regpep.2007.09.021.

52. Bai L, Zhang X, Li X, Liu N, Lou F, Ma H, Luo X, Ren Y. Somatostatin prevents lipopolysaccharide-induced neurodegeneration in the rat substantia nigra by inhibiting the activation of microglia. Mol Med Rep. 2015;12(1):1002-8. https://doi.org/10.3892/mmr.2015.3494.

53. ter Veld F, Rose B, Mussmann R, Martin S, Herder C, Kempf K. Effects of somatostatin and octreotide on cytokine and chemokine production by lipopolysaccharide-activated peripheral blood mononuclear cells. J Endocrinol Invest. 2009;32(2):123-9.

54. Sergeyev $V$, Broberger $C$, Hökfelt T. Effect of LPS administration on the expression of POMC, NPY, galanin, CART and MCH mRNAs in the rat hypothalamus. Brain Res Mol Brain Res. 2001;90(2):93-100.

55. Lyudyno VI, Krasnova IN, Smirnova MP, Klimenko VM. Antipyretic effect of neuropeptide galanin in endotoxin-induced fever. Bull Exp Biol Med. 2001;131(1):60-3.

56. Felies M, von Hörsten S, Pabst R, Nave H. Neuropeptide Y stabilizes body temperature and prevents hypotension in endotoxaemic rats. J Physiol. 2004;561(Pt1):245-52. https://doi.org/10.1113/jphysiol.2004.073635.

57. Brito HO, Barbosa FL, Reis RC, Fraga D, Borges BS, Franco CR, Zampronio AR. Evidence of substance P autocrine circuitry that involves TNF- $a, I L-6$, and PGE2 in endogenous pyrogen-induced fever. J Neuroimmunol. 2016;29:1-7. https://doi.org/10.1016/j.jneuroim.2016.01.016.

58. Ferreira R, Santos T, Viegas M, Cortes L, Bernardino L, Vieira OV, Malva JO. Neuropeptide $Y$ inhibits interleukin-1 $\beta$-induced phagocytosis by microglial cells. J Neuroinflamm. 2011;169(8):1-15. https://doi. org/10.1186/1742-2094-8-169.

59. Hauser GJ, Dayao EK, Zukowska-Grojec Z. Effect of neuropeptide Y on endotoxin-induced suppression of the response to various agonists in conscious rats. Life Sci. 1995;57(3):235-44.

60. Miura A, Hino H, Uchida K, Inoue S, Tateda T. Peripheral nerve conduction abnormalities precede morphological alterations in an experimental rat model of sepsis. J Anesth. 2016;30(6):961-9. https://doi.org/10.1007/ s00540-016-2247-5.

61. Hunter R, Ojha U, Bhurtel S, Bing G, Choi DY. Lipopolysaccharide-induced functional and structural injury of the mitochondria in the nigrostriatal pathway. Neurosci Res. 2017;114:62-9. https://doi.org/10.1016/j. neures.2016.09.007.

62. Wang $X H$, Xie $X$, Luo $X G$, Shang $H$, He ZY. Inhibiting purinergic P2X7 receptors with the antagonist brilliant blue $\mathrm{G}$ is neuroprotective in an intranigral lipopolysaccharide animal model of Parkinson's disease. Mol Med Rep. 2017;15(2):768-76. https://doi.org/10.3892/mmr.2016.6070.

63. Meneses G, Bautista M, Florentino A, Díaz G, Acero G, Besedovsky H, Meneses D, Fleury A, Del Rey A, Gevorkian G, Fragoso G, Sciutto E. Electric stimulation of the vagus nerve reduced mouse neuroinflammation induced by lipopolysaccharide. J Inflamm. 2016;13(33):1-11. https://doi. org/10.1186/s12950-016-0140-5.

64. Benson S, Kattoor J, Wegner A, Hammes F, Reidick D, Grigoleit JS, Engler $\mathrm{H}$, Oberbeck R, Schedlowski M, Elsenbruch S. Acute experimental endotoxemia induces visceral hypersensitivity and altered pain evaluation in healthy humans. Pain. 2012;153:794-9. https://doi.org/10.1016/j. pain.2011.12.001.

65. Garcia-Oscos F, Peña D, Housini M, Cheng D, Lopez D, Cuevas-Olguin R, Saderi N, Salgado Delgado R, Galindo Charles L, Salgado Burgos H, RoseJohn S, Flores G, Kilgard MP, Atzori M. Activation of the anti-inflammatory reflex blocks lipopolysaccharide-induced decrease in synaptic inhibition in the temporal cortex of the rat. J Neurosci Res. 2015;93:859-65. https:// doi.org/10.1002/jnr.23550.

66. Mikołajczyk A. Safe and effective anaesthesiological protocols in domestic pigs. Ann Warsaw Univ Life Sci SGGW Anim Sci. 2016;55(2):219-27.

67. Llamas-Moya S, Boyle L, Arkins S, Lynch PB. Effects of husbandry and low-dose lipopolysaccharide challenge on the acute phase response of young pigs. End of Project Report no 5231, Teagsac. 2006; p. 1-38. http:// hdl.handle.net/11019/982.

68. Llamas-Moya S, Boyle L, Lynch P, Arkins S. Pro-inflammatory cytokine and acute phase protein responses to low-dose lipopolysaccharide (LPS) 
challenge in pigs. Anim Sci. 2006;82(4):527-34. https://doi.org/10.1079/ ASC200665.

69. Qin L, Wu X, Block ML, Liu Y, Breese GR, Hong JS, Knapp DJ, Crews FT. Systemic LPS causes chronic neuroinflammation and progressive neurodegeneration. Glia. 2007;55:453-62. https://doi.org/10.1002/glia.20467.

70. Rivera-Aguilar V, Querejeta E, Jarillo-Luna RA, Reyna-Garfias H, PonceFranco D, Milliar-Garcia A, Quiñones-Cárdenas AR, Pacheco-Yepez J, Campos-Rodríguez R. Role of the striatum in the humoral immune response to thymus-independent and thymus-dependent antigens in rats. Immunol Lett. 2008;120:20-8. https://doi.org/10.1016/j.imlet.2008.06.006.

71. Conlon JM. Purification of naturally occurring peptides by reversedphase HPLC. Nat Protoc. 2007;2(1):191-7. https://doi.org/10.1038/ nprot.2006.437.

\section{Submit your next manuscript to BioMed Central and we will help you at every step:}

- We accept pre-submission inquiries

- Our selector tool helps you to find the most relevant journal

- We provide round the clock customer support

- Convenient online submission

- Thorough peer review

- Inclusion in PubMed and all major indexing services

- Maximum visibility for your research

Submit your manuscript at

www.biomedcentral.com/submit 